Lawless, Jennifer L., and Richard L. Fox. 2005. It Takes a Candidate: Why Women Don't Run for Office. New York: Cambridge University Press.

MacNell, Lillian, Adam Driscoll, and Andrea N. Hunt. 2015. "What's in a Name: Exposing Gender Bias in Student Ratings of Teaching." Innovative Higher Education 40 (4): 291-303.

Mason, Mary Ann, Nicholas H. Wolfinger, and Marc Goulden. 2014. Do Babies Matter? Gender and Family in the Ivory Tower. New Brunswick, NJ: Rutgers University Press.

Shames, Shauna, Rachel Bernhard, Mirya R. Holman, and Dawn Teele. 2020. Good Reasons to Run. Philadelphia: Temple University Press.

Teele, Dawn. 2020. "What's Wrong with Replicating the Old Boy's Network?" In The Production of Knowledge: Enhancing Progress in Social Science, ed. Colin Elman, John Gerring, and James Mahoney. New York: Cambridge University Press.

Winslow, Sarah. 2010. "Gender Inequality and Time Allocations Among Academic Faculty." Gender \& Society 24 (6): 769-93.

\section{WALKING IN LARGE FOOTPRINTS AND FORGING NEW PATHS}

\section{Wendy Schiller, Brown University}

\section{DOI: $10.1017 / S_{1049096519002166}$}

I entered graduate school in political science at the University of Rochester in 1989 after several years working in the US Senate and lobbying for the Office of the State of New York. I was originally hoping to study voting behavior, but then I took one class with Linda Powell on legislative behavior and I was hooked on Congress. Late in the spring of my first year at Rochester, Linda told me that Richard (Dick) Fenno was looking for a research assistant starting that summer and asked if I would be interested. As my best friend Fiona McGillivray remarked that day, "Well, that's a career maker." And she was right.

I often think about what might have happened if Linda Powell had not taught that class my first year; that she was a senior female professor studying public opinion, legislative politics, and campaign finance; who was impressive to me both for her research and because she was (and still is) a successful female academic. What if she had not passed on the job opportunity with one of the most famous Congress scholars in the past 50 years? Would I have sought out that opportunity on my own? Probably not. Would I today? Absolutely.

In addition to Linda Powell, Rochester already had produced several female PhDs who made their mark in the field of legislative studies, including Christine DeGregorio, Diana Evans, Linda Fowler, and Barbara Decker Sinclair, among others. Later, at Princeton on a postdoc, I met Carol Swain who had just won the Woodrow Wilson APSA award for Black Faces, Black Interests: The Representation of African Americans in Congress (Swain 1993). Because of the encouragement and success of women who had come before me in the field, I did not see barriers to entry to the field of legislative studies. When I published my first article on bill sponsorship in the Senate in the American Journal of Political Science (Schiller 1995), it seemed as if the sky would be the limit for publishing more quantitative work on the Senate in other journals. In that era, most of the peer-reviewed articles that were published on Congress featured the House of Representatives, which had the advantage of a more formal rules structure and a much larger $\mathrm{N}$ than the Senate. However, throughout the 1990 and early 200os, work on the Senate became more quantitative, and technology allowed for a broader analysis of individual legislative behavior of the type that dominated Senate life more so than the House.

In general, I sought to publish other articles associated with my dissertation and projects on the Senate, but I encountered more rejection than success. What I did not do was persevere and seek a wider range of outlets for my published work. Facing rejection at the "top" journals, I shelved manuscripts instead of revising and resubmitting them. Years later, I realize that for most people reading a CV-especially university administrators-a longer list of published articles always ranks higher than a shorter list of articles in more prestigious journals. This is a key lesson for younger colleagues, both female and male.

I also found that coauthorship networks tended to be male dominated, but that very well could have been a function of the ratio of male to female graduate students in the area of legislative studies rather than a purposeful exclusionary practice. These types of networks also were evident in the "circuit" of presenting papers in departmental seminars, which was a key way of having work recognized and improving it for potential reviewers who could be chosen from these seminars. Women coming up in the field should not hesitate to ask their colleagues in other departments to invite them for talks to present their work; when there is an opportunity in their own department to run a seminar series, they should be sure to reciprocate. Parallel to this would be trying to secure invitations to smaller conferences that increasingly are becoming important incubators for published work. There were fewer of these types of conferences 20 years ago, but now they frequently produce opportunities to vet articles and book ideas.

Women scholars in legislative studies also should be encouraged to apply for grants, ranging from the Dirksen Center research grants to National Science Foundation (NSF) grants, to fund their work. Grants are not important only for securing the resources to conduct research; they also are key to establishing the external validity of work and forging a distinct reputation among department colleagues and administrators. In my case, as a tenured associate professor, I worked with Charles Stewart (of MIT)—who was senior to me in rank and reputation in the area of congressional history-to secure an NSF grant to study the indirect elections of US Senators. He and I had separately been pursuing parallel tracks on the question of indirect Senate elections, and it seemed to be a good opportunity to work together. Some observers would argue that it is exactly the wrong strategy for a woman in choosing research partnerships because men frequently receive more credit for joint projects than their female colleagues. However, that was not my experience at all. We worked together successfully, presenting papers and publishing an article and a book from the project. Although gendered asymmetry in rank is not always an advisable feature on coauthorship partnerships, doing so to pursue major grants and publications can further a career.

For legislative scholars today, as in prioryears, publishing a book rather than a series of journal articles may still be the "gold standard" for staking out intellectual property rights. The year I started graduate school (1989), Barbara Sinclair published The Transformation of the US Senate and Steve Smith published Call to Order: Floor Politics in the House and Senate, which were foundational in their push to study the Senate on par with the House. It would be seven to 10 more years before Sarah Binder and Steve Smith published Politics or Principle? Filibustering in the United States Senate (1996); Frances Lee and Bruce Oppenheimer published Sizing up the Senate: The Unequal Consequences of Equal Representation (1999); and I published Partners and Rivals: Representation in US Senate Delegations (200o). It would be another 10 years after that when we could argue that the Senate would reach almost parity with the House as the subject of exploration in the legislative studies subfield. This was demonstrated by an increase in peer-reviewed journal articles and books, including Party Polarization in Congress by 
Sean Theriault (2008) and Beyond Ideology: Politics, Principles, and Partisanship in the US Senate by Frances Lee (2009).

In addition to Sinclair, Binder, and Lee, women scholars in legislative studies have made their mark on the field with important books ranging from Michele Swers's 2002 work on women in Congress in The Difference Women Make: The Policy Impact of Women in Congress; to Katherine Tate's work (2003) on black representation in Black Faces in the Mirror: African Americans and Their Representatives in the US Congress; to Tracy Sulkin's work (2005) on the impact of campaigns on agenda setting in Issue Politics in Congress; to Laurel Harbridge's work (2015) on bipartisan lawmaking in Is Bipartisanship Dead? Policy Agreement and Agenda-Setting in the House of Representatives; to Gisela Sin's work (2014) on structural distribution of power in Separation of Powers and Legislative Organization; to Kathryn Pearson's work (2015) on party leadership in Party Discipline in the US House of Representatives. This more recent cohort of female scholars in legislative politics is carrying on the tradition of their predecessors and pushing the boundaries of legislative scholarship much farther. What marks these women as fundamentally different and strategically savvy is that they also published articles in a range of journals on their book topics, as well as other subjects.

Given the expansion of the discipline of political science, women have much more choice in their areas of specialization. However, on the face of it, the landscape for legislative scholars is more constrained than in prior decades. The degree of polarization and centralized party control in both chambers has produced gridlock as well as a smaller space for individual entrepreneurship and less overall legislating. There must be stories to tell and puzzles to explain, and Congress has not been cooperative in this regard. But the beauty of studying the American Congress is that every two years, the cast of characters can change and party control sometimes changes with them. In 2018, the shift in leadership control of the House, as well as the election of more black and Latino legislators, created the potential for renewed research on legislative agenda setting and intersectionality in representation. This is an opportunity to increase the number and success of women in legislative studies, starting with encouraging female students at the undergraduate level to pursue a $\mathrm{PhD}$ in political science and then making sure that they climb every rung of the proverbial ladder with as much confidence, ambition, and strategic self-promotion as their male colleagues.

\section{REFERENCES}

Binder, Sarah, and Steven Smith. 1996. Politics or Principle? Filibustering in the United States Senate. Washington, DC: Brooking Institution Press.

Harbridge, Laurel. 2015. Is Bipartisanship Dead? Policy Agreement and Agenda-Setting in the House of Representatives. New York: Cambridge University Press.

Lee, Frances. 2009. Beyond Ideology: Politics, Principles, and Partisanship in the US Senate. Chicago: University of Chicago Press.

Lee, Frances, and Bruce Oppenheimer. 1999. Sizing up the Senate: The Unequal Consequences of Equal Representation. Chicago: University of Chicago Press.

Pearson, Kathryn. 2015. Party Discipline in the US House of Representatives. Ann Arbor: University of Michigan Press.

Schiller, Wendy J. 1995. "Senators as Political Entrepreneurs: Using Bill Sponsorship to Shape Legislative Agendas." American Journal of Political Science 1: 186-203.

Schiller, Wendy J. 200o. Partners and Rivals: Representation in the US Senate Delegations. Princeton, NJ: Princeton University Press.

Sin, Gisela. 2014. Separation of Powers and Legislative Organization. New York: Cambridge University Press.

Sinclair, Barbara. 1989. The Transformation of the US Senate. Baltimore, MD: Johns Hopkins University Press.

Smith, Steven. 1989. Call to Order: Floor Politics in the House and Senate. Washington, DC: Brookings Institution Press.

Sulkin, Tracy. 2005. Issue Politics in Congress. New York: Cambridge University Press.

Swain, Carol. 1993. Black Faces, Black Interests: The Representation of African Americans in Congress. Lanham, MD: University Press of America.

Swers, Michele. 2002. The Difference Women Make: The Policy Impact of Women in Congress. Chicago: University of Chicago Press.

Tate, Katherine. 2003. Black Faces in the Mirror: African Americans and Their Representatives in the US Congress. Princeton, NJ: Princeton University Press.

Theriault, Sean. 2008. Party Polarization in Congress. New York: Cambridge University Press.

\section{SPOTLIGHT CONTRIBUTORS}

Nadia E. Brown is a university scholar and associate professor of political science and African American Studies at Purdue University. She can be reached at brown957@purdue.edu.

Guillermo Caballero is a second-year doctoral student in political science at Purdue University specializing in American politics, public policy, and social movements. He can be reached at gcaballe@purdue.edu.

Linda L. Fowler is professor of government and Frank J. Reagan Chair in Policy Studies at Dartmouth College, emerita, where she continues to teach and conduct research. She can be reached at Linda.L.Fowler@Dartmouth.edu.

Laurel Harbridge-Yong is associate professor in political science and a faculty fellow with the Institute for Policy Research, both at Northwestern University. She can be reached at 1-hardbridge@northwestern.edu.

Patricia A. Hurley is professor emerita of political science and former department head and associate dean of liberal arts at Texas A\&M University. She can be reached at pat-hurley@tamu.edu.

Jasmine C. Jackson is a second-year graduate student in political science at Purdue University. She can be reached atjacks6o4@purdue.edu.
Frances E. Lee is professor of government and politics at Princeton University. She can be reached atfrances.lee@princeton.edu.

Carol Mershon is professor of politics at the University of Virginia. For more information, see her website that includes her contact information and Google scholar profile.

Dana Moyer is a PhD candidate in politics at the University of Virginia. She can be reached at dkm4ra@virginia.edu.

Liza Mügge is associate professor in political science and director of the Amsterdam Research Centre for Gender and Sexuality at the University of Amsterdam. She can be reached at1.m.mugge@uva.nl.

Diana Z. O'Brien is associate professor of political science at Texas AEM University. She can be reached at dzobrien@rice.edu.

Sanne van Oosten is a PhD candidate in political science at the University of Amsterdam. She can be reached at S.B.vanOOsten@uva.nl.

Lynda Powell is professor of political science at the University of Rochester. She can be reached at lynda.powell@rochester.edu.
Cindy Simon Rosenthal is emeritus professor of political science and women and gender studies at the University of Oklahoma. She can be reached at csrosenthal@ou.edu.

Wendy Schiller is professor of political science and international and public affairs, and chair of the Department of Political Science at Brown University. She can be reached at wendy_schiller@brown.edu.

Gisela Sin is associate professor of political science at the University of Illinois at Urbana-Champaign. She can be reached at gsin@illinois.edu.

Tracy Sulkin is professor of political science at the University of Illinois at Urbana-Champaign. She can be reached at tsulkin@illinois.edu.

Michele Swers is professor of American government at Georgetown University. She can be reached at mls47@georgetown.edu.

SoRelle Wyckoff Gaynor is a second-year PhD student at the University of Maryland studying the US Congress and public policy. She can be reached at sorellew@umd.edu. 